\title{
Impact of Foliar Feeding With Alga Extract and Boron on Yield and Quality of Sugar Beet Grown in Sandy Soil
}

S.A.A.M. Enan, A. M. El-Saady ${ }^{*}$ and A. B. El-Sayed ${ }^{*}$

Agron. Dept., Sugar Crops Res. Inst., Agric. Res. Center and

*Fert. Technol. Dept., National Research Centre, Cairo, Egypt.

\begin{abstract}
TWO FIELD experiments were conducted at Wadi El-Natrun, 1 El-Bahira Governorate, (latitude of $30.48^{\circ} \mathrm{N}$ and longitude of $30.50^{\circ}$ E) during $2013 / 2014$ and $2014 / 2015$ seasons to study the impact of foliar application with alga extract (Spirulina platensis) and boron on yield and quality of sugar beet (Beta vulgaris var. saccharifera, L.) planted in a sandy soil under sprinkler irrigation system. The present work included sixteen treatments, represented the combinations of four alga extract levels (without; $1.5 ; 2.5$ and $3.5 \mathrm{~g} /$ liter) sprayed twice at 4-6 and 6-8 leaf stages as well as four concentrations of boron (without; 50; 100 and $150 \mathrm{ppm} / \mathrm{liter} / \mathrm{fad}$, as boric acid $17 \%$ boron) which, sprayed twice at 6-8 and 10 leaf stages. The treatments were arranged in a strip plot design in three replicates. The vertical plots were occupied with four levels of alga extract and the horizontal plots were devoted to the four levels of boron.
\end{abstract}

The Results indicated that foliar application of alga extract using $2.5 \mathrm{~g} / \mathrm{l}$ or $3.5 \mathrm{~g} / \mathrm{l}$ produced significantly higher values of photosynthetic pigments (chlorophyll $\mathrm{a}, \mathrm{b}$ and carotenoides), vegetative growth traits of sugar beet plants (root diameter, root and foliage fresh weight), (root and top dry weight/plant), extractable sugar $\%$, quality index $\%$, nitrogen, phosphorus, potassium, boron contents in leaves and root, top and sugar yields/fad, as well as the lowest content of sodium in roots in both seasons.

Higher values of root diameter, fresh weight/plant, root, top and sugar yields/fad, sucrose, extractable sugar, quality index percentages and boron contents in leaves and roots, at harvesting time, were obtained with spraying boron at $100 \mathrm{ppm} / \mathrm{fad}$ in both seasons.

The interaction between alga extract and boron levels significantly affected chlorophyll (a), root fresh weight/plant in both seasons; chlorophyll (b), and root yield/fad in $1^{\text {st }}$ one. The combination of $3.5 \mathrm{~g} / \mathrm{l}$ alga extract along with $100 \mathrm{ppm}$ boron can be recommended to get the maximum root yield/fad $(27.13 \mathrm{t} / \mathrm{fad})$ in $1^{\text {st }}$ season, which showed an integrative role between fertilization using the alga extract and boron.

Keywords: Spirulina, Boron, Sandy soil, Sugar beet.

Sugar beet is one of the most imperative cash crops in the world. The continued production of this important commodity requires more crop management 
techniques. In addition the broad-leaved crop increases soil fertility, especially in newly cultivated soils which, characterized with low of organic matter and water holding capacity as well as high nutrient losses by leaching; which leads to show deficiency symptoms of macro and micro nutrients (Shafeek et al., 2013). Algae extract being organic and bio-degradable in nature is considered as an important source of nutrition for sustainable agriculture especially in the newly reclaimed soil. Chemical analysis of algae extract and have revealed the presence of a wide variety of plant growth regulators such as auxins and cytokinins in varying amounts (Zhang \& Ervin, 2004). Thus, algae extract stimulate root establishment, root elongation and promote vegetative growth of plants. Foliar application of algae extract has been reported to induce many positive effects, where spraying plants had led to improve crop yield and quality, increase nutrient uptake, resistance to frost and stress conditions. Algae were early considered as an important group of microorganisms capable of fixing atmospheric nitrogen, as well as it causes significant increase in root growth, fresh and dry weights of roots, total biomass, yield component, photosynthetic pigments and growth promoting hormones (Ghalab \& Salem, 2001). As a result of the functional activity, there is an increase of photosynthetic apparatus through raising the contents of total carbohydrates, starch, amino acids and protein (Raupp \& Oltmanns, 2006 and Yassen et al., 2007). Spirulina platensis is a rich source of potassium and contains considerable amounts of $\mathrm{Ca}, \mathrm{Cu}, \mathrm{Fe}, \mathrm{Mg}$, $\mathrm{Mn}, \mathrm{P}$ and $\mathrm{Zn}$, hence it increases uptake and accumulation of these elements in plants. This in turn explains the significant increase of vegetative growth and yield and its components as well as content of nitrogen, phosphorus and protein in leaves also leaf chlorophyll content for most crops especially those grown under semi arid and desert conditions (Abd El-Mawgoud et al., 2010 and Marrez et al., 2014).

Boron is by far the most important trace element needed by sugar beet because without an adequate supply, the yield and quality of roots is very depressed (Cooke \& Scott, 1993). Its plays a key role in higher plants by facilitating the short-and long-distance transport of sugar via the formation of borate-sugar complexes. In addition, boron may be of importance for maintaining the structural integrity of plasma plant cells membranes. This function is likely related to stabilization of cell membranes by boron association with some membrane constituents (Brown et al., 2002). Foliar spraying with boron have the advantage that they enable an existing deficiency problem to be treated rapidly. Several studies showed the beneficial effect of boron on the sugar beet, such as Kristek et al. (2006). They studied the effect of foliar fertilization with $1.0 \mathrm{~kg} \mathrm{~B} / \mathrm{ha}$ on root yield and quality of sugar beet compared with the control. They found that higher values of root, sugar yields/fad and sucrose \% was obtained with the previous concentration mentioned of boron. Enan (2011) showed that higher values of root diameter, fresh weight/plant, root, top and sugar yields/fad, sucrose $\%$ and boron concentration in root and leaves were obtained with increasing boron application up to $200 \mathrm{ppm} / \mathrm{fad}$. Armin \& Asgharipour (2012) indicated that highest root yield/fad and sucrose\% were obtained by spraying with $12 \%$ boric acid, furthermore decreasing potassium,

Egypt. J. Agron. 38, No. 2 (2016) 
sodium, alpha amino-N contents and sugar lost to molasses compared with the control treatment. Abbas et al. (2014) showed that application of boron showed significant increase in most traits where, increasing boron fertilizer up to $0.20 \mathrm{~g} / \mathrm{l}$ resulted in highest sucrose, sugar recovery percentages, recoverable sugar yield/fad and purity $\%$ compared to check treatment.

This study aiming to evaluate the effect of alga extract as a source of biostimulator on sugar beet, which is considered as an important strategic crop and has extensively growth potential in reclamated soils with possibility to select the optimum dose of the alga extract and of boron levels for maximizing yield and quality under sprinkler irrigation system in sandy soil.

\section{Materials and Methods}

Two field experiments were conducted at Wadi El-Natrun, El-Bahira Governorate, (latitude of $30.48^{0} \mathrm{~N}$ and longitude of $30.50^{\circ} \mathrm{E}$ ) during 2013/2014 and 2014/2015 seasons to study the impact of foliar application with alga extract (Spirulina platensis) and boron on yield and quality of sugar beet (Beta vulgaris var. saccharifera, L.) planted in a sandy soil under sprinkler irrigation system. The present work included sixteen treatments, represented the combinations of four alga extract levels (without; $1.5,2.5$ and $3.5 \mathrm{~g} / 1 / 350$ liter water/fad) sprayed twice at 4-6 and 6-8 leaf stages as well as four concentrations of boron (without; 50,100 and $150 \mathrm{ppm} / 450$ liter water/fad, as boric acid $17 \%$ boron) which, sprayed twice at 6-8 and 10 leaf stages. The treatments were arranged in a strip plot design in three replicates. The vertical plots were occupied with four levels of alga extract while, the horizontal plots were devoted to the four levels of boron. The plot area was $21.60 \mathrm{~m}^{2}$ including 12 rows of $4-\mathrm{m}$ in length and $45-\mathrm{cm}$ between them, with $17-\mathrm{cm}$ hill spacing filled with one seed per hill. Phosphorus fertilizer was applied in the form of calcium super phosphate $\left(15 \% \mathrm{P}_{2} \mathrm{O}_{5}\right)$ at the rate of $200 \mathrm{~kg} / \mathrm{fad}$ at seed bed preparation. Nitrogen fertilizer was applied as ammonium nitrate at the rate of $100 \mathrm{~kg} \mathrm{~N} / \mathrm{fad}$, which was split as follows: $10 \mathrm{~kg}$ $\mathrm{N} / \mathrm{fad}$ at age of 20 days after sowing, followed by $10 \mathrm{~kg} \mathrm{~N} / \mathrm{fad}$, two doses of $25 \mathrm{~kg}$ $\mathrm{N} / \mathrm{fad}$ were added twice as a soil application after hoeing, $20 \mathrm{~kg} \mathrm{~N} / \mathrm{fad}$ at age of 80 days after sowing and $10 \mathrm{~kg} \mathrm{~N} / \mathrm{fad}$ at 100 days from sowing. Potassium fertilizer was added in the form of potassium sulphate $\left(48 \% \mathrm{~K}_{2} \mathrm{O}\right)$ with irrigation water at the rate of $48 \mathrm{~kg} /$ fad before canopy closer. Sugar beet was sown mechanically under sprinkler irrigation system. Sowing of sugar beet variety mono-germ "GENIO" took place during the $1^{\text {st }}$ week of October, while harvesting was done 7 months later in both seasons.

\section{Algal extract preparation}

The early isolated blue green alga Spirulina platensis from Wadi El-Natrun, El-Bahira Governorate was scaled up to massive scale at Algal Biotechnology Unit, National Research Centre within three open ponds $\left(75 \mathrm{~m}^{3}\right.$ of a final capacity). Continuous centrifugation (Westifalia Separator) was employed for harvesting algal bulk which contains 75-80\% moisture and then after freeze for $48 \mathrm{~h}$ at $-25^{\circ} \mathrm{C}$. Prior centrifugation, algal slurry was drastically stressed by hyper 
nutritional doses to meet obligatory nutrient accumulation within algal cells. The frozen bulk was then re-melted at the room temperature, homogenized and an aerobically fermented $72 \mathrm{~h}$. The fermented biomass was then homogenized and filtered till it used. Major components of the used alga extract are shown in Table 1.

TABLE 1. Chemical composition of some macro and micro-nutrients of alga biofertilizer.

\begin{tabular}{|c|c|c|c|c|c|c|c|c|c|c|}
\hline Elements & $\mathbf{N}$ & $\mathbf{P}$ & $\mathbf{K}$ & $\mathbf{M g}$ & $\mathbf{N a}$ & $\mathbf{C a}$ & $\mathbf{F e}$ & $\mathbf{Z n}$ & $\mathbf{M n}$ & $\mathbf{C u}$ \\
\hline \multirow{2}{*}{ Conc. } & \multicolumn{8}{|c|}{$\%$} & \multicolumn{5}{|c|}{$\mathrm{ppm}$} \\
\cline { 2 - 9 } & 11.2 & 1.65 & 0.88 & 0.22 & 0.01 & 0.33 & 1936 & 21 & 68 & 18 \\
\hline
\end{tabular}

Some soil physical properties were analyzed using the procedure described by Black et al. (1981). Soil chemical analysis was determined according to the method of Jackson (1973). Physical and chemical analyses of the soil (the upper $60-\mathrm{cm})$ of the experimental site are given in Table 2.

TABLE 2. Particle size distribution and some chemical properties of a representative soil sample of the experimental site for 2013-2014 and 2014-2015 seasons.

\begin{tabular}{|c|c|c|}
\hline Soil properties & 2013/2014 season & 2014/2015 season \\
\hline \multicolumn{3}{|l|}{ Particle size distribution: } \\
\hline Coarse sand \% & 30.89 & 27.95 \\
\hline Fine sand \% & 61.01 & 64.00 \\
\hline Silt & 6.20 & 6.00 \\
\hline Clay & 1.90 & 2.05 \\
\hline Texture class & Sandy & Sandy \\
\hline Organic Matter \% & 0.37 & 0.41 \\
\hline Available Nitrogen $\mathrm{mg} / \mathrm{kg}$ soil & 11.50 & 12.60 \\
\hline Available $\mathrm{P}_{2} \mathrm{O}_{5} \mathrm{mg} / \mathrm{kg}$ soil & 3.65 & 4.00 \\
\hline Available $\mathrm{K}_{2} \mathrm{O} \mathrm{mg} / \mathrm{kg}$ soil & 75.3 & 80.1 \\
\hline Available boron $\mathrm{mg} / \mathrm{kg}$ soil & 0.12 & 0.15 \\
\hline $\mathrm{pH}$ at (1:2.5) soil : water suspension & 7.94 & 8.01 \\
\hline E.C dS. $/ \mathrm{m}^{-1}$ & 0.45 & 0.35 \\
\hline \multicolumn{3}{|l|}{ Soluble Cations (meq.//1-1) } \\
\hline $\mathrm{K}^{+}$ & 1.50 & 1.14 \\
\hline $\mathrm{Na}^{+}$ & 0.80 & 0.76 \\
\hline $\mathrm{Mg}^{++}$ & 1.20 & 0.90 \\
\hline $\mathrm{Ca}^{++}$ & 0.89 & 0.75 \\
\hline \multicolumn{3}{|l|}{ Soluble Anions (meq./ $\mathrm{l}^{-1}$ ) } \\
\hline $\mathrm{SO}_{4}=$ & 1.39 & 0.89 \\
\hline $\mathrm{Cl}^{-}$ & 2.1 & 1.80 \\
\hline $\mathrm{HCO}_{3}^{-}$ & 0.90 & 0.86 \\
\hline $\mathrm{CO}_{3}{ }^{=}$ & - & - \\
\hline
\end{tabular}

Egypt. J. Agron. 38, No. 2 (2016) 


\section{The recorded data}

After 105 days from sowing, random samples of five sugar beet plants were taken from each sub plot to determine chlorophyll $\mathrm{a}, \mathrm{b}$ and carotenoides $(\mathrm{mg} / \mathrm{g}$ leaf fresh weight) according to the method of Wettstein (1957).

At harvest time, the following traits were estimated:

\section{Yield components}

1. Root length and diameter $(\mathrm{cm})$.

2. Root and top fresh weight (g/plant).

3. Root and leaves dry weights as g/plant which were determined as follows: 100 $\mathrm{g}$ of the fresh leaves and minced fresh roots were oven dried at $70{ }^{\circ} \mathrm{C}$ to a constant weight, then the dry matter percentages of these two portions were multiplied by their fresh weight/plant.

Chemical and quality characteristics

4. Sucrose percentage (Pol\%) was estimated in fresh samples of sugar beet roots, using Saccharometer according to the method described in A.O.A.C. (2005).

5. Sugar lost to molasses percentage (SLM \%) was calculated by the following formula, according to Devillers (1988):

$\mathrm{SLM} \%=0.29+(\mathrm{Na}+\mathrm{K}) 0.343+0.094(\alpha$-amino $\mathrm{N})$.

6. Juice quality percentage (QZ \%) was calculated according to Cooke \& Scott (1993) using the following equation:

$\mathrm{QZ} \%=($ extractable sugar $\% \times 100) / \mathrm{Pol} \%$.

7. Impurities\%: $\mathrm{K}, \mathrm{Na}$ and $\alpha$-amino $\mathrm{N}$ contents were estimated as meq/100 $\mathrm{g}$ beet according to the procedure of sugar company using an Automated Analyzer as described in Cooke \& Scott (1993).

8. Extractable sugar $\%$ was calculated using the following equation according to Cooke \& Scott (1993):

Extractable sugar $\%=(\mathrm{Pol} \%-0.29)-0.343(\mathrm{~K}+\mathrm{Na})-\alpha-$ amino $\mathrm{N}(0.0939)$.

where: $\mathrm{K}, \mathrm{Na}$ and $\alpha$-amino $\mathrm{N}$ were determined as meq $/ 100 \mathrm{~g}$ beet.

9.Foliage contents of $\mathrm{N}, \mathrm{P}, \mathrm{K}$ and B:The dry matter of leaves was digested using an acid mixture consisting of nitric, perchloric and sulfuric acids in the ratio of 8:1:1 (v/v), respectively (Chapman \& Pratt, 1978). Nitrogen (N) was determined using micro-Kjeldahl method, using boric acid modification described by Ma \& Zuazage (1942) and distillation was done using Gerhardt apparatus. Phosphorus was spectro-photometrically determined using the molybdate-vanadate method according to Jackson (1973). Potassium was measured using Dr. Lang-M8D Flame-photometer. Boron was extracted with hot water and determined colourimetrically using azomethine- $\mathrm{H}$ according to the method described by Wolf (1974).

Root , top and sugar yields/fad (t/fad

Plants of six guarded rows were uprooted, topped and weighed to determine the following parameters:

10. Top yield (fad).

11. Root yield (fad). 
12. Sugar yield (fad), which was calculated according to following equation:

Sugar yield $(\mathrm{fad})=$ roots yield $(\mathrm{fed}) \mathrm{x}$ sugar recovery $\%$.

All data statistically analyzed according to the technique of analysis of variance (ANOVA) for the strip plot design as published by Gomez \& Gomez (1984) by means of "MSTAT-c" computer software package. Least significant differences between treatment means at $5 \%$ level of probability as described by Snedecor \& Cochran (1980).

\section{Results and Discussion}

Photosynthetic pigments, root diameter, root and foliage fresh weights/plant

Data in Table 3 manifest that a significant effect of Spirulina extract on photosynthetic pigments, root diameter, root and foliage fresh weights/plant, in both seasons. Spraying beet plants with 2.5 or $3.5 \mathrm{~g} / \mathrm{l}$ Spirulina extract resulted in higher values of photosynthetic pigments and root thickness as well as fresh weight of leaves and roots as compared to the other levels (i.e.; control and $1.5 \mathrm{~g} / \mathrm{l}$ ). There were significant difference between 2.5 and $3.5 \mathrm{~g} / \mathrm{l}$ Spirulina extract in their effect on root fresh weight/plant and root diameter in both seasons concerning foliage fresh weight in $1^{\text {st }}$ season and root diameter in $2^{\text {nd }}$ season. The appreciable influence of alga extract may be attributed to its effect in increasing cell membrane permeability and promoting plant efficiency in the absorption of nutrients such as nitrogen, which has a direct relation with leaf chlorophyll concentration. Moreover, algae extract may play a role through its content of cytokinins in delaying the aging of leaves by reducing the degradation of chlorophyll. In addition, alga extract as a bio-regulator affecting the balance between photosynthesis and respiration processes in plants (Raupp \& Oltmanns, 2006 and Yassen et al., 2007).

TABLE 3.Photosynthetic pigments $(\mathrm{mg} / \mathrm{g}$ fresh weight), root diameter $(\mathrm{cm})$, root and foliage fresh weight (g/plant) as affected by foliar application of Spirulina extract concentrations in 2013/2014 and 2014/2015 seasons.

\begin{tabular}{|c|c|c|c|c|c|c|}
\hline \multirow{2}{*}{$\begin{array}{l}\text { Alga extract conc. } \\
(\mathrm{g} / \mathrm{l})\end{array}$} & \multicolumn{3}{|c|}{$\begin{array}{l}\text { Photosynthetic pigments } \\
\text { (mg/g f.w.) }\end{array}$} & \multirow{2}{*}{$\begin{array}{c}\text { Root } \\
\text { diameter } \\
\text { (cm) }\end{array}$} & \multirow{2}{*}{$\begin{array}{c}\text { Root fresh } \\
\text { weight } \\
\text { (g/plant) }\end{array}$} & \multirow{2}{*}{$\begin{array}{c}\text { Foliage } \\
\text { fresh } \\
\text { weight } \\
\text { (g/plant) }\end{array}$} \\
\hline & Chl. a & Chl. b & Carotenoids & & & \\
\hline \multicolumn{7}{|c|}{ 2013/2014 seasons } \\
\hline Without alga extract & 1.33 & 0.71 & 0.51 & 8.13 & 550.0 & 221.9 \\
\hline 1.5 & 1.77 & 1.01 & 0.71 & 8.98 & 670.0 & 287.3 \\
\hline 2.5 & 2.37 & 1.22 & 0.87 & 9.56 & 709.6 & 296.3 \\
\hline 3.5 & 2.67 & 1.35 & 0.89 & 9.97 & 776.5 & 364.0 \\
\hline LSD at $0.05 \%$ level & 0.42 & 0.27 & $\mathbf{0 . 1 3}$ & 1.05 & 66.10 & 0.63 \\
\hline \multicolumn{7}{|c|}{ 2014/2015 seasons } \\
\hline Without alga extract & 1.98 & 0.60 & 0.36 & 7.11 & 552.1 & 230.4 \\
\hline 1.5 & 2.09 & 1.07 & 0.54 & 7.86 & 619.5 & 304.6 \\
\hline 2.5 & 2.64 & 1.21 & 0.73 & 8.52 & 637.5 & 330.0 \\
\hline 3.5 & 2.83 & 1.45 & 0.64 & 9.20 & 719.5 & 353.8 \\
\hline LSD at $0.05 \%$ level & 0.52 & 0.39 & 0.16 & 0.62 & 69.43 & 0.69 \\
\hline
\end{tabular}

Egypt. J. Agron. 38, No. 2 (2016) 
Concerning the effect of boron levels, data in Table 4 cleared that fertilizing sugar beet with $100 \mathrm{ppm}$ of boron led to the positive effects of boron on root diameter, foliage and root fresh weights/plant and carotenoids in both seasons, whilst insignificant differences between boron levels in their impact on chlorophyll (a) in both seasons and also in their effect on chlorophyll (b) in $1^{\text {st }}$ season only. This result may be due to role of boron element in cell elongation where, in case of boron deficiency the leaves are smaller, stiff and thick also its role for the formation of new leaves. Moreover it has an active role in translation of assimilation product of the leaves and roots. Similar results were reported by Kristek et al. (2006), Enan (2011) and Abbas et al. (2014).

TABLE 4. Photosynthetic pigments (mg/g fresh weight), root diameter (cm), root and foliage fresh weight (g/plant) as affected by foliar application of boron fertilization in 2013/2014 and 2014/2015 seasons.

\begin{tabular}{|c|c|c|c|c|c|c|}
\hline \multirow{2}{*}{$\begin{array}{c}\text { Boron } \\
\text { treatments } \\
(\mathbf{p p m})\end{array}$} & \multicolumn{3}{|c|}{$\begin{array}{c}\text { photosynthetic pigments } \\
\text { (mg/g f.w) }\end{array}$} & \multirow{2}{*}{$\begin{array}{c}\text { Root } \\
\text { diameter } \\
(\mathbf{c m})\end{array}$} & \multirow{2}{*}{$\begin{array}{c}\text { Root } \\
\text { fresh } \\
\text { weight } \\
\text { (g/plant) }\end{array}$} & \multirow{2}{*}{$\begin{array}{c}\text { Foliage } \\
\text { fresh } \\
\text { weight } \\
\text { (g/plant) }\end{array}$} \\
\hline & Chl. a & Chl. b & Carotenoids & & & \\
\hline \multicolumn{7}{|c|}{ 2013/2014 season } \\
\hline $\begin{array}{l}\text { Without } \\
\text { boron }\end{array}$ & 1.81 & 1.00 & 0.67 & 8.72 & 595.7 & 251.7 \\
\hline 50 & 2.00 & 1.09 & 0.74 & 9.23 & 679.4 & 286.6 \\
\hline 100 & 2.21 & 1.15 & 0.82 & 9.45 & 739.2 & 317.6 \\
\hline 150 & 2.11 & 1.06 & 0.76 & 9.25 & 691.8 & 313.6 \\
\hline $\begin{array}{l}\text { LSD at } 0.05 \% \\
\text { level }\end{array}$ & NS & NS & 0.06 & 0.13 & 45.8 & 21.0 \\
\hline \multicolumn{7}{|c|}{$2014 / 2015$ season } \\
\hline $\begin{array}{l}\text { Without } \\
\text { boron }\end{array}$ & 2.07 & 0.93 & 0.44 & 7.88 & 600.8 & 280.0 \\
\hline 50 & 2.34 & 1.06 & 0.54 & 7.99 & 636.3 & 303.8 \\
\hline 100 & 2.61 & 1.19 & 0.69 & 8.72 & 662.9 & 327.1 \\
\hline 150 & 2.50 & 1.17 & 0.58 & 8.10 & 628.6 & 307.9 \\
\hline $\begin{array}{l}\text { LSD at } 0.05 \% \\
\text { level }\end{array}$ & NS & 0.11 & 0.10 & 0.55 & 27.3 & 20.0 \\
\hline
\end{tabular}

The interaction between Spirulina extract and boron fertilization levels had a significant effect on chlorophyll (a) and root fresh weight/plant in both seasons as well as chlorophyll (b) in $1^{\text {st }}$ season (Tables 3 and 4).

\section{Effect of interactions}

Chlorophyll (a) was significantly affected by the interaction between Spirulina extract and boron fertilization levels in both seasons. The results in Table 5 showed that chlorophyll (a) was responded to the increase of foliar applied Spirulina extract level, but was highly magnituded by adding 100 ppm boron. Therefore the highest value of leaf tissue content of chlorophyll (a) was recorded by 2.5 and/or $3.5 \mathrm{~g} / \mathrm{l}$ alga extract without significant differences between them when plants received $100 \mathrm{ppm}$ boron in $1^{\text {st }}$ and $2^{\text {nd }}$ season. This 
finding may be due to algae extract contains cytokines which induce the physiological activities and increase total chlorophyll in plants which, reflects on the activity of photosynthesis and the synthesized materials which will positively reflects on the growth characteristics (Ghalab \& Salem, 2001).

TABLE 5. Chlorophyll (a) as affected by the interaction between Spirulina extract and boron fertilization levels in 2012/2013 and 2013/2014 seasons.

\begin{tabular}{|c|c|c|c|c|c|c|c|c|}
\hline Boron & & $13 / 20$ & seaso & & & $14 / 201$ & season & \\
\hline & $\begin{array}{c}\text { Without } \\
\text { boron } \\
\text { (control) }\end{array}$ & $\begin{array}{c}50 \\
\text { ppm }\end{array}$ & $\begin{array}{r}100 \\
\text { ppm }\end{array}$ & $\begin{array}{r}150 \\
\text { ppm }\end{array}$ & $\begin{array}{c}\text { Without } \\
\text { boron } \\
\text { (control) }\end{array}$ & $\begin{array}{c}50 \\
\text { ppm }\end{array}$ & $\begin{array}{r}100 \\
\text { ppm }\end{array}$ & $\begin{array}{r}150 \\
\text { ppm }\end{array}$ \\
\hline Alga extract & & & & & & & & \\
\hline $\begin{array}{l}\text { Without alga } \\
\text { extract }\end{array}$ & 1.23 & 1.26 & 1.45 & 1.36 & 1.88 & 1.96 & 2.09 & 1.99 \\
\hline $1.5 \mathrm{~g} / \mathrm{l}$ & 1.68 & 1.70 & 1.88 & 1.81 & 1.89 & 2.10 & 2.25 & 2.11 \\
\hline $2.5 \mathrm{~g} / \mathrm{l}$ & 1.85 & 2.41 & 2.69 & 2.54 & 2.02 & 2.69 & 3.00 & 2.84 \\
\hline $3.5 \mathrm{~g} / 1$ & 2.47 & 2.64 & 2.82 & 2.74 & 2.50 & 2.61 & 3.13 & 3.07 \\
\hline LSD at $0.05 \%$ level & & & & & & 0. & & \\
\hline
\end{tabular}

Data in Table 6 clear that the difference in chlorophyll (b) content in leaf tissue of sugar beet fertilized with 1.5 and $2.5 \mathrm{~g} / \mathrm{l}$ alga extract/fad was significant, when plants received $100 \mathrm{ppm}$ boron whilst, the difference between these two levels of alga extract under the other levels of boron was insignificant. Application of 2.5 and/or $3.5 \mathrm{~g} / \mathrm{l}$ alga extract/fad combined with $100 \mathrm{ppm}$ boron/fad gave the highest value for content of chlorophyll (b), in 2013/2014 season.

TABLE 6. Chlorophyll (b) as affected by the interaction between Spirulina extract concentration and boron fertilization levels in 2013/2014 season.

\begin{tabular}{|l|c|c|c|c|}
\hline \multirow{2}{*}{ Boron } & \multicolumn{4}{|c|}{$\mathbf{2 0 1 3 / 2 0 1 4}$ seasons } \\
\cline { 2 - 5 } & $\begin{array}{c}\text { Without } \\
\text { boron (control) }\end{array}$ & $\mathbf{5 0} \mathbf{~ p p m}$ & $\begin{array}{c}\mathbf{1 0 0} \\
\text { ppm }\end{array}$ & $\begin{array}{c}\mathbf{1 5 0} \\
\text { ppm }\end{array}$ \\
\hline Without alga extract & 0.40 & 0.81 & 0.84 & 0.79 \\
\hline $1.5 \mathrm{~g} / \mathrm{l}$ & 0.99 & 1.05 & 0.97 & 1.00 \\
\hline $2.5 \mathrm{~g} / \mathrm{l}$ & 1.17 & 1.19 & 1.33 & 1.16 \\
\hline $3.5 \mathrm{~g} / \mathrm{l}$ & 1.32 & 1.33 & 1.47 & 1.28 \\
\hline LSD at $\mathbf{0 . 0 5} \%$ level & & \multicolumn{4}{|c|}{$\mathbf{0 . 2 0}$} \\
\hline
\end{tabular}

Egypt. J. Agron. 38, No. 2 (2016) 
Data in Table 7 show that the difference in root fresh weight/plant between beets which received $50 \mathrm{ppm}$ boron and those untreated with boron was insignificant when sugar beet was unfertilized with alga extract, fertilized with 1.5 and $3.5 \mathrm{~g} / \mathrm{l}$ alga extract/fad. However, the difference in this trait between those two levels of boron was significant under fertilized with $2.5 \mathrm{~g} / \mathrm{l}$ alga extract in $1^{\text {st }}$ season. In the $2^{\text {nd }}$ one, the difference in this trait between those two levels of boron was significant under those fertilized with 2.5 and/or $3.5 \mathrm{~g} / \mathrm{l}$ alga extract/fad. Application of $3.5 \mathrm{~g} / \mathrm{l}$ alga extract $+100 \mathrm{ppm}$ boron/fad gave the highest value for root fresh weight/plant, in both seasons.

TABLE 7. Root fresh weight (g/plant) as affected by the interaction between Spirulina extract concentration and boron fertilization level in 2012/2013 and 2013/2014 seasons.

\begin{tabular}{|c|c|c|c|c|c|c|c|c|}
\hline \multirow[b]{2}{*}{$\begin{array}{l}\text { Alga } \\
\text { extract conc. }\end{array}$} & \multicolumn{4}{|c|}{$2013 / 2014$ seasons } & \multicolumn{4}{|c|}{$2014 / 2015$ seasons } \\
\hline & $\begin{array}{l}\text { Without } \\
\text { boron } \\
\text { (control) }\end{array}$ & $50 \mathrm{ppm}$ & $\begin{array}{l}100 \\
\text { ppm }\end{array}$ & $\begin{array}{l}150 \\
\text { ppm }\end{array}$ & $\begin{array}{c}\text { Without } \\
\text { boron } \\
\text { (control) }\end{array}$ & $\begin{array}{c}50 \\
\text { ppm }\end{array}$ & $\begin{array}{l}100 \\
\text { ppm }\end{array}$ & $\begin{array}{l}150 \\
\text { ppm }\end{array}$ \\
\hline $\begin{array}{l}\text { Without alga } \\
\text { extract }\end{array}$ & 485.0 & 501.7 & 576.7 & 516.7 & 531.7 & 561.7 & 563.3 & 551.7 \\
\hline $1.5 \mathrm{~g} / 1$ & 585.0 & 620.0 & 686.7 & 668.3 & 606.7 & 626.7 & 645.0 & 599.7 \\
\hline $2.5 \mathrm{~g} / 1$ & 630.0 & 713.3 & 768.3 & 726.7 & 573.3 & 636.7 & 690.0 & 650.0 \\
\hline $3.5 \mathrm{~g} / 1$ & 758.3 & 778.3 & 821.7 & 751.7 & 681.7 & 720.0 & 753.3 & 723.0 \\
\hline LSD at $0.05 \%$ level & \multicolumn{4}{|c|}{39.96} & \multicolumn{4}{|c|}{31.0} \\
\hline
\end{tabular}

Root, top dry weight/plant, nitrogen, phosphorus, potassium and boron contents in leaves (mg/loo g plant)

Root and top dry weight of sugar beet plants recorded higher values by spraying beets with 2.5 or $3.5 \mathrm{~g} / 1$ Spirulina extract, without significant difference between them, in both seasons (Table 8). Increasing the applied level of alga extract up to $2.5 \mathrm{~g} / \mathrm{l}$ resulted in a gradual and significant increases in $\mathrm{N}, \mathrm{P}$ and $\mathrm{B}$ contents in sugar beet leaves in both seasons. Meantime, the highest $\mathrm{K}$ content was recoded when beets received $3.5 \mathrm{~g} / \mathrm{l}$ of alga extract, without significant variance with $2.5 \mathrm{~g} / \mathrm{l}$ of alga extract in both seasons. These results may be due to that alga extract is considered a source of high protein which split into natural amino acids involved directly in the metabolism (Marrez et al., 2014). It also contains some essential macronutrients for growth and development of the plant as $\mathrm{N}, \mathrm{P}$ and $\mathrm{K}$. In addition, algae extract affect the nutrients uptake by plant roots (Abd El-Mawgoud et al., 2010). 
TABLE 8. Root (g/plant), top dry weight (g/plant); nitrogen, phosphorus, potassium and boron contents in leaves $(\mathrm{mg} / 100 \mathrm{~g}$ plant) as affected by foliar application of Spirulina extract concentration level in 2013/2014 and 2014/2015 seasons.

\begin{tabular}{|c|c|c|c|c|c|c|}
\hline $\begin{array}{l}\text { Alga treatments } \\
\text { concentration } \\
\text { g/l }\end{array}$ & $\begin{array}{l}\text { Root dry } \\
\text { weight } \\
\text { (g/plant) }\end{array}$ & $\begin{array}{c}\text { Top dry } \\
\text { weight } \\
\text { (g/plant) }\end{array}$ & $\begin{array}{c}\mathrm{N} \\
\text { content } \\
(\mathrm{mg} / 100 \mathrm{~g} \\
\text { plant })\end{array}$ & $\begin{array}{c}\mathbf{P} \\
\text { content } \\
(\mathbf{m g} / 100 \mathrm{~g} \\
\text { plant })\end{array}$ & $\begin{array}{c}\mathrm{K} \\
\text { content } \\
\text { (mg/100 g } \\
\text { plant) }\end{array}$ & $\begin{array}{c}\text { Boron } \\
\text { content } \\
\text { (mg/100 g } \\
\text { plant) }\end{array}$ \\
\hline \multicolumn{7}{|c|}{ 2013/2014 season } \\
\hline Without alga & 135.9 & 25.73 & 298.7 & 24.42 & 359.7 & 0.55 \\
\hline 1.5 & 186.7 & 28.29 & 538.4 & 43.11 & 521.1 & 0.74 \\
\hline 2.5 & 213.3 & 29.25 & 753.8 & 62.84 & 584.9 & 0.93 \\
\hline 3.5 & 200.8 & 31.71 & 724.9 & 60.62 & 666.2 & 0.86 \\
\hline LSD at $0.05 \%$ level & 46.0 & 2.75 & 210.0 & 18.0 & 119.5 & 0.12 \\
\hline \multicolumn{7}{|c|}{$2014 / 2015$ season } \\
\hline Without alga & 145.0 & 21.7 & 305.9 & 28.64 & 342.3 & 0.36 \\
\hline 1.5 & 178.3 & 26.0 & 419.2 & 49.39 & 479.8 & 0.62 \\
\hline 2.5 & 225.0 & 28.6 & 596.0 & 74.05 & 633.1 & 0.95 \\
\hline 3.5 & 215.0 & 27.9 & 528.2 & 68.45 & 591.9 & 0.81 \\
\hline LSD at $0.05 \%$ level & 37.5 & 4.0 & 161.0 & 22.0 & 0.97 & 0.15 \\
\hline
\end{tabular}

The results in Table 9 reveal that sprayind beets with 100 or 150 ppm boron recorded higher values of root and top dry weights/plants without significant difference between them in root dry weight/plant, boron content in leaves in both seasons and top dry weight/plant in $2^{\text {nd }}$ season. Feeding sugar beet with $100 \mathrm{ppm}$ boron/fad led to significant effect on top dry weight/plant in $1^{\text {st }}$ season compared with the rest of the levels used. Phosphorus content was not affected by levels of boron in both seasons. Similarly, leaf potassium content was insignificantly influenced by boron levels, in the $2^{\text {nd }}$ season. These results may be due to differential absorption of these nutrients in the presence of boron, which enhance some elements on the account of others in the bio-accumulation of nitrogen (Hellal et al., 2009), especially in sandy soil which contain low of organic matter and micronutrients such as boron (Table 2).

The interaction between Spirulina extract and boron fertilization levels had insignificant effect on the above-mentioned traits (Tables 8 and 9).

Sucrose \%, (potassium, sodium, alpha-amino contents meq/100 g beet), sugar lost to molasses and extractable sugar percentages

Data in Table 10 show that sucrose \%, potassium and alpha-amino-N in both seasons, as well as sugar lost to molasses (in $1^{\text {st }}$ season) and extractable sugar percentages (in $2^{\text {nd }}$ season) were insignificantly influenced by the applied alga extract concentrations. Meantime, the fertilization with $2.5 \mathrm{~g} / \mathrm{l}$ and/or $3.5 \mathrm{~g} / \mathrm{l}$ alga extract led to higher values of extractable sugar percentage in $1^{s t}$ season. Feeding beet plants with $3.5 \mathrm{~g} / \mathrm{l}$ reduced sodium content amounted to $22.36 \%$ and $39.06 \%$ in the $1^{s t}$ and $2^{\text {nd }}$ seasons respectively, as well as reduced sugar lost to molasses $\%$ amounted to $6.80 \%$ in the $2^{\text {nd }}$ season, as compared to that gained by fertilizing beets with $2.5 \mathrm{~g} / \mathrm{l}$ alga extract. 
TABLE 9. Root, top dry weight/plant, nitrogen, phosphour, potassium and boron contents in leaves $(\mathrm{mg} / 100 \mathrm{~g}$ plant) as affected by foliar application of boron fertilization levels in $2013 / 2014$ and $2014 / 2015$ seasons.

\begin{tabular}{|c|c|c|c|c|c|c|}
\hline $\begin{array}{l}\text { Boron treatments } \\
(\text { ppm) }\end{array}$ & $\begin{array}{l}\text { Root dry } \\
\text { weight } \%\end{array}$ & $\begin{array}{c}\text { Top dry } \\
\text { weight } \%\end{array}$ & \begin{tabular}{|c|}
$\mathrm{N}$ \\
content in \\
leaves \\
(mg/100 $\mathrm{g}$ \\
plant) \\
\end{tabular} & \begin{tabular}{|c|}
$P$ \\
content in \\
leaves \\
$(\mathrm{mg} / 100 \mathrm{~g}$ \\
plant $)$ \\
\end{tabular} & \begin{tabular}{|c|}
$\mathrm{K}$ \\
content in \\
leaves \\
$(\mathrm{mg} / 100 \mathrm{~g}$ \\
plant $)$
\end{tabular} & $\begin{array}{c}\text { Boron } \\
\text { content in } \\
\text { leaves } \\
\text { (mg/100 } \mathrm{g} \\
\text { plant) }\end{array}$ \\
\hline \multicolumn{7}{|c|}{$2013 / 2014$ season } \\
\hline Without boron & 168.8 & 27.75 & 539.1 & 45.39 & 444.4 & 0.68 \\
\hline 50 & 175.5 & 28.63 & 558.4 & 49.13 & 534.6 & 0.74 \\
\hline 100 & 194.2 & 29.50 & 604.4 & 49.53 & 589.6 & 0.83 \\
\hline 150 & 198.3 & 29.11 & 613.8 & 46.94 & 563.3 & 0.82 \\
\hline LSD at $0.05 \%$ level & 12.0 & 0.32 & 39.0 & NS & 44.0 & 0.07 \\
\hline \multicolumn{7}{|c|}{$2014 / 2015$ season } \\
\hline Without boron & 176.7 & 25.4 & 396.4 & 52.14 & 471.7 & 0.48 \\
\hline 50 & 187.5 & 25.8 & 443.1 & 55.31 & 515.9 & 0.66 \\
\hline 100 & 197.5 & 26.4 & 502.3 & 57.98 & 529.6 & 0.78 \\
\hline 150 & 201.7 & 26.7 & 507.5 & 55.10 & 529.8 & 0.84 \\
\hline LSD at $0.05 \%$ level & 10.0 & $\mathbf{0 . 8 0}$ & $\mathbf{0 . 2 3}$ & NS & NS & 0.11 \\
\hline
\end{tabular}

TABLE 10. Sucrose \%, potassium, sodium, alpha-amino content (meq/100 g beet), sugar lost to molasses and extractable sugar $(\%)$ as affected by Spirulina extract concentration in 2013/2014 and 2014/2015 seasons.

\begin{tabular}{|c|c|c|c|c|c|c|}
\hline $\begin{array}{l}\text { Alga } \\
\text { treatments } \\
\text { conc. }(g / l)\end{array}$ & $\begin{array}{c}\text { Sucrose } \\
\%\end{array}$ & $\begin{array}{c}\text { Potassium } \\
\text { (meq/100 g } \\
\text { beet) }\end{array}$ & $\begin{array}{c}\text { Sodium } \\
(\text { meq/100 g } \\
\text { beet })\end{array}$ & \begin{tabular}{|c|} 
Alpha \\
amino-N \\
$\left(\begin{array}{c}\text { meq/100 } \mathrm{g} \\
\text { beet })\end{array}\right.$ \\
\end{tabular} & \begin{tabular}{|c} 
Sugar lost \\
to \\
molasses \\
$\%$
\end{tabular} & $\begin{array}{c}\text { Extractable } \\
\text { sugar \% }\end{array}$ \\
\hline \multicolumn{7}{|c|}{ 2013/2014 season } \\
\hline Without alga & 15.96 & 3.95 & 2.11 & 1.81 & 2.55 & 13.41 \\
\hline 1.5 & 16.38 & 3.77 & 2.06 & 1.62 & 2.45 & 13.94 \\
\hline 2.5 & 16.49 & 3.73 & 1.97 & 1.44 & 2.39 & 14.10 \\
\hline 3.5 & 16.65 & 3.69 & 1.61 & 1.40 & 2.25 & 14.40 \\
\hline $\begin{array}{l}\text { LSD at \%0.05 } \\
\text { level }\end{array}$ & NS & NS & 0.35 & NS & NS & 0.57 \\
\hline \multicolumn{7}{|c|}{ 2014/2015 season } \\
\hline Without alga & 15.54 & 3.75 & 2.05 & 1.39 & 2.42 & 13.13 \\
\hline 1.5 & 15.62 & 3.70 & 1.89 & 1.34 & 2.34 & 13.28 \\
\hline 2.5 & 15.81 & 3.63 & 1.78 & 1.23 & 2.20 & 13.61 \\
\hline 3.5 & 15.90 & 3.49 & 1.28 & 1.32 & 2.06 & 13.84 \\
\hline $\begin{array}{l}\text { LSD at } 0.05 \% \\
\text { level }\end{array}$ & NS & NS & 0.50 & NS & 0.25 & NS \\
\hline
\end{tabular}


Data in Table 11 show that sucrose \%, sodium, potassium contents in roots, sugar lost to molasses and extractable sugar percentages were significantly affected by the spraying beet plants with boron levels, while alpha-amino $\mathrm{N}$ failed to reach the level of significance in both seasons. Fertilizing beet plants with $100 \mathrm{ppm}$ of boron recorded highest values of sucrose and extractable sugar $\%$, in addition to lowest quantities of sodium, potassium contents and sugar lost to molasses\% compared to other treatments. Adding boron at the rate of $100 \mathrm{ppm}$ achieved an increase in sucrose amounted to 1.16, 1.00 and an increase in extractable sugar amounted to $1.56,1.35$ over those unfertilized in $1^{\text {st }}$ and $2^{\text {nd }}$ season, respectively. Meantime, the significant lowest quantities of sodium and sugar lost to molasses\% was recorded by supplying $100 \mathrm{ppm}$ boron application compared with the check treatment, 50 and $150 \mathrm{ppm}$ boron/fad. These results may be due to that boron levels significantly increased glucose levels in phloem sap and the balance in sodium uptake and nitrogen consumption. As well as the borate ion react with hydroxyl rich substances such as sugar to produce legends which were then transported more rapidly across membranes than un-dissociated free sugar, which led to boron gave more facilities to sugar movement from the leaves to roots. These finding are in agreement with that mentioned by Javaheripour et al. (2005) who stated that increasing the amount of boric acid to a certain extent can reduce molasses sugar as a result of decreasing in impurities in terms of $\mathrm{Na}, \mathrm{K}$ and alpha-amino nitrogen content in beet roots.

The interaction between Spirulina extract and boron fertilization levels failed to reach the level of significance in their effect on the above-mentioned traits in both seasons (Tables 10 and 11).

TABLE 11. Sucrose \%, (potassium, sodium, alpha-amino contents meq/100 g beet), sugar lost to molasses and extractable sugar percentages as affected by boron fertilization levels in 2013/2014 and 2014/2015 seasons.

\begin{tabular}{|c|c|c|c|c|c|c|}
\hline $\begin{array}{l}\text { Boron treatments } \\
(\mathrm{ppm})\end{array}$ & $\mid \begin{array}{c}\text { Sucrose } \\
\%\end{array}$ & $\begin{array}{c}\text { Potassium } \\
\text { (meq/100 g } \\
\text { beet) }\end{array}$ & $\begin{array}{c}\text { Sodium } \\
(\mathrm{meq} / \mathbf{1 0 0} \\
\mathrm{g} \text { beet })\end{array}$ & $\begin{array}{c}\text { Alpha } \\
\text { amino-N } \\
\left(\begin{array}{c}\text { meq/100 g } \\
\text { beet })\end{array}\right.\end{array}$ & \begin{tabular}{|c|}
$\begin{array}{c}\text { Sugar } \\
\text { lost to } \\
\text { molasses } \\
\%\end{array}$ \\
\end{tabular} & $\begin{array}{c}\text { Extractable } \\
\text { sugar \% }\end{array}$ \\
\hline \multicolumn{7}{|c|}{ 2013/2014 season } \\
\hline Without boron & 15.76 & 4.06 & 2.22 & 1.56 & 2.59 & 13.16 \\
\hline 50 & 16.33 & 3.67 & 1.95 & 1.52 & 2.37 & 13.96 \\
\hline 100 & 16.92 & 3.58 & 1.58 & 1.47 & 2.21 & 14.72 \\
\hline 150 & 16.48 & 3.84 & 2.00 & 1.72 & 2.46 & 14.02 \\
\hline LSD at $0.05 \%$ level & 0.51 & 0.26 & 0.19 & NS & 0.14 & 0.53 \\
\hline \multicolumn{7}{|c|}{$2014 / 2015$ season } \\
\hline Without boron & 15.16 & 3.94 & 1.89 & 1.41 & 2.43 & 12.73 \\
\hline 50 & 15.63 & 3.72 & 1.73 & 1.25 & 2.28 & 13.34 \\
\hline 100 & 16.16 & 3.29 & 1.55 & 1.25 & 2.08 & 14.08 \\
\hline 150 & 15.93 & 3.62 & 1.62 & 1.37 & 2.22 & 13.71 \\
\hline LSD at $0.05 \%$ level & 0.30 & 0.37 & 0.23 & NS & 0.16 & 0.38 \\
\hline
\end{tabular}

Egypt. J. Agron. 38, No. 2 (2016) 
Quality index\%, root, top and sugar yields/fad

Data in Table 12 indicate a significant effect on root, top and sugar yields/fad due to the fertilization with Spirulina extract levels in both seasons. Feeding sugar beet plants with 2.5 or $3.5 \mathrm{~g} / \mathrm{l}$ alga extract/fad without significant difference between them gave higher values of these traits compared with check treatment and those that received $1.5 \mathrm{~g} / \mathrm{l}$ alga extract, while there was insignificant difference between beets fertilized with 2.5 and $3.5 \mathrm{~g} / \mathrm{l}$. Application of $3.5 \mathrm{~g} / \mathrm{l}$ alga extract led to an increase in root, top and sugar yields/fad amounted to $3.05,1.57$ and 0.67 tons/fad, compared that gained by check treatment in $1^{\text {st }}$ season, respectively. In the $2^{\text {nd }}$ one, the increase in these traits amounted to $2.52,1.92$ and 0.50 tons/fad respectively, compared to the untreated treatment with alga extract. The augmentation in root, top and sugar yields/fad may be due to the increase in plant growth parameters (Tables 3 and 8), which in turn is reflected on root, top yields/fad depending on the theory of the source and downstream. As for the quality index, it turned out to be significantly affected by adding 2.5 and/or $3.5 \mathrm{~g} / \mathrm{l}$ alga extract without significant differences between them in the $1^{\text {st }}$ season. In the $2^{\text {nd }}$ one, the variance in this trait between alga extract concentrations used was insignificant.

TABLE 12. Quality index, root, top and sugar yields/fad as affected by foliar application of Spirulina extract concentration in 2013/2014 and 2014/2015 seasons.

\begin{tabular}{|l|c|c|c|c|}
\hline $\begin{array}{l}\text { Alga treatments } \\
\text { conc. g/l }\end{array}$ & $\begin{array}{c}\text { Quality } \\
\text { Index }\end{array}$ & $\begin{array}{c}\text { Root yield } \\
\text { t/fad }\end{array}$ & $\begin{array}{c}\text { Top yield } \\
\text { t/fad }\end{array}$ & $\begin{array}{c}\text { Sugar } \\
\text { yield t/fad }\end{array}$ \\
\hline \multicolumn{5}{|c|}{$\mathbf{2 0 1 3 / 2 0 1 4}$ season } \\
\hline Without alga extract & 83.97 & 23.53 & 8.46 & 3.76 \\
\hline 1.5 & 85.02 & 25.17 & 9.20 & 4.13 \\
\hline 2.5 & 85.45 & 25.78 & 9.90 & 4.25 \\
\hline 3.5 & 86.54 & 26.58 & 10.03 & 4.43 \\
\hline LSD at 0.05\% level & $\mathbf{1 . 4 8}$ & $\mathbf{1 . 5 0}$ & $\mathbf{0 . 6 7}$ & $\mathbf{0 . 2 1}$ \\
\hline \multicolumn{5}{|c|}{$\mathbf{2 0 1 4 / 2 0 1 5}$ season } \\
\hline Without alga extract & 85.47 & 22.82 & 7.48 & 3.54 \\
\hline 1.5 & 86.07 & 24.09 & 8.24 & 3.77 \\
\hline 2.5 & 84.80 & 24.64 & 8.55 & 3.90 \\
\hline 3.5 & 85.26 & 25.34 & 9.40 & 4.04 \\
\hline LSD at $\mathbf{0 . 0 5} \%$ level & $\mathbf{N S}$ & $\mathbf{1 . 2 5}$ & $\mathbf{0 . 7 1}$ & $\mathbf{0 . 1 7}$ \\
\hline
\end{tabular}

Quality index, root, top and sugar yields/fad in Table 13 increased significantly when boron level was raised from zero up to $100 \mathrm{ppm}$ boron/fad in both seasons. Supplying sugar beet with $100 \mathrm{ppm}$ boron resulted in a positive effect surpassing the level of $150 \mathrm{ppm}$ boron on quality index $\%$ in both seasons and top yield/fad in $1^{\text {st }}$ season, while there was insignificant difference between 100 and $150 \mathrm{ppm}$ boron on root, sugar yields/fad in both seasons and top yield/fad in $2^{\text {nd }}$ season. This increase in root, top, sugar yields/fad and quality index accompanying boron may be due to the increase in root diameter, root, top fresh weights/plant and sucrose $\%$ as mentioned before (Tables 4 and 11). These 
results are in harmony with those obtained by Kristek et al. (2006), Enan (2011) and Armin \& Asgharipour (2012)

The interaction between Spirulina extract and boron fertilization levels had insignificant effect on the above-mentioned traits, with the exception of root yield/fad in $1^{\text {st }}$ season (Tables 12 and 13).

TABLE 13. Quality index, root, top and sugar yields/fad as affected by foliar application of Spirulina extract concentration in 2013/2014 and 2014/2015 seasons.

\begin{tabular}{|l|c|c|c|c|}
\hline $\begin{array}{l}\text { Boron treatments } \\
\text { ppm) }\end{array}$ & Quality index & $\begin{array}{c}\text { Root yield } \\
\text { t/fad }\end{array}$ & $\begin{array}{c}\text { Top yield } \\
\text { t/fad }\end{array}$ & $\begin{array}{c}\text { Sugar yield } \\
\text { t/fad }\end{array}$ \\
\hline \multicolumn{5}{|c|}{$\mathbf{2 0 1 3 / 2 0 1 4}$ season } \\
\hline Without boron & 83.43 & 24.41 & 9.08 & 3.85 \\
\hline 50 & 85.47 & 25.19 & 9.35 & 4.11 \\
\hline 100 & 86.97 & 25.94 & 9.74 & 4.40 \\
\hline 150 & 85.11 & 25.52 & 9.44 & 4.21 \\
\hline LSD at $\mathbf{0 . 0 5 \%}$ level & $\mathbf{0 . 8 7}$ & $\mathbf{0 . 7 4}$ & $\mathbf{0 . 2 1}$ & $\mathbf{0 . 2 0}$ \\
\hline & $\mathbf{2 0 1 4 / 2 0 1 5}$ season & & 3.53 \\
\hline Without boron & 84.79 & 23.27 & 8.13 & 3.77 \\
\hline 50 & 84.96 & 24.13 & 8.38 & 4.03 \\
\hline 100 & 86.50 & 24.95 & 8.61 & 3.91 \\
\hline 150 & 85.35 & 24.54 & 8.55 & $\mathbf{0 . 1 3}$ \\
\hline LSD at $\mathbf{0 . 0 5 \%}$ level & $\mathbf{1 . 0 0}$ & $\mathbf{0 . 7 0}$ & $\mathbf{0 . 1 4}$ & \\
\hline
\end{tabular}

\section{Interaction effect}

Root yield/fad was significantly affected by the interaction between Spirulina extract concentrations and boron levels in 2013/2014 season. The results in Table 14 show that the differences in root yield/fad between beets sprayed with $50 \mathrm{ppm}$ and those unfertilized with boron were insignificant, in the case of plants unfertilized with Spirulina extract, plants fad with 1.5 and $3.5 \mathrm{~g} / \mathrm{l}$ Spirulina extract. The differences in root yield/fad between beets sprayed with $100 \mathrm{ppm}$ and those that sprayed with $50 \mathrm{ppm}$ were insignificant in the case of plants fertilized with 1.5 and $3.5 \mathrm{~g} / \mathrm{l}$ Spirulina extract. Based on that spraying beet plants with $100 \mathrm{ppm}$ boron/fad resulted in a higher value of root yield/fad, when beets was fad with 2.5 and/or $3.5 \mathrm{~g} / 1$ Spirulina extract without significant differences between them. 
TABLE 14. Root yield/fad as affected by the interaction between Spirulina extract and boron fertilization levels in 2013/2014 season.

\begin{tabular}{|l|c|c|c|c|}
\hline \multirow{2}{*}{ Boron } & \multicolumn{4}{|c|}{$\mathbf{2 0 1 3 / 2 0 1 4}$ season } \\
\cline { 2 - 5 } Alga extract conc. & $\begin{array}{c}\text { Without } \\
\text { boron (control) }\end{array}$ & $\begin{array}{c}\mathbf{5 0} \mathbf{~ p p m} \\
\text { boron }\end{array}$ & $\begin{array}{c}\mathbf{1 0 0} \mathbf{~ p p m} \\
\text { boron }\end{array}$ & $\begin{array}{c}\mathbf{1 5 0} \mathbf{~ p p m} \\
\text { boron }\end{array}$ \\
\hline Without alga extract & 22.88 & 23.01 & 24.18 & 24.06 \\
\hline $1.5 \mathrm{~g} / \mathrm{l}$ & 24.60 & 25.13 & 25.76 & 25.17 \\
\hline $2.5 \mathrm{~g} / \mathrm{l}$ & 23.85 & 25.70 & 26.85 & 26.72 \\
\hline $3.5 \mathrm{~g} / \mathrm{l}$ & 26.30 & 26.76 & 27.13 & 26.15 \\
\hline LSD at $\mathbf{0 . 0 5 \%}$ level & \multicolumn{4}{|c|}{$\mathbf{1 . 0 9}$} \\
\hline
\end{tabular}

\section{Conclusion}

Spirulina extract when applied as a foliar application, can contribute to the supply of plant nutrients and substitute nutrients. On the results of this study, it can be recommended to spray sugar beet with 2.5 or $3.5 \mathrm{~g} / \mathrm{l}$ of Spirulina extract along with $100 \mathrm{ppm}$ boron for maximum yields of root and sugar under sandy soil conditions.

\section{Referances}

A.O.A.C. (2005) Association of official analytical chemists. "Official Methods of Analysis", $26^{\text {th }}$ ed. AOAC International, Washington, D.C; USA.

Abbas, M.S., Dewdar, M.D.H., El-Sayed, G.I. and Abd El-Aleem, H.A. (2014) Impact of boron foliar application on quantity and quality traits of sugar beet (Beta vulgaris L.) in Egypt. Res. J. Pharma. Biol. Chem. Sci. 5 (5), 143-151.

Abd El-Mawgoud, A.M.R., Tantawy, A.S., El-Nemr, M.A. and Sassine, Y.N. (2010) Growth and yield responses of strawberry plants to chitosan application. Europ. J. Scientific Res.39 (1), 161-168.

Armin, M. and Asgharipour, M.R. (2012) Effect of time and concentration of boron foliar application on yield and quality of sugar beet. Am. Eur. J. Agric. Environ. Sci. 12 (4), 444-448.

Black, C. A., Evans., D. D., Ensminger, L.E., White, G. L. and Clark, F. E. (1981) "Methods of Soil Analysis". Part 2. Pp. 1-100. Agron. Inc. Madison. WI., USA.

Brown, P. H., Bellaloui, N., Wimmer, M. A., Bassil, E.S., Ruiz, J., Hu, H., Pfeffer, H., Dannel, F. and Romheld, V. (2002) Boron in plant biology, Plant Biol. 4, 205223.

Chapman, H.D. and Pratt, P.F. (1978) "Methods of Analysis for Soils, Plants and Waters". Division of Agricultural Sciences, University of California, Berkeley, USA, 3043 pp.

Cooke, D.A. and Scott, R.K. (1993) “The Sugar Beet Crop". Science Practice. Puplished by Chapman and Hall, London. 
Devillers, P. (1988) Prevision du sucremelasse. Scurries francases 129, 190-200.

Enan, S.A.A.M. (2011) Effect of transplanting and foliar fertilization with potassium and boron on yield and quality traits of sugar beet sown under saline conditions. J. Biol. Chem. Environ. Sci. 6 (2), 525-546.

Ghalab, A.M. and Salem, S.A. (2001) Effect of biofertilizer treatments on growth, chemical composition and productivity of wheat grown under different levels of NPK fertilization. Annal Agric. Sci. 46, 485-509.

Gomez, K. A. and Gomez, A. A. (1984) "Statistical Procedures for Agriculture Research". $2^{\text {nd }}$ ed., "A Wiley Interscience Publication", John Wiley and Sons, New Youk.

Hellal, F.A., Taalab, A.S. and Safaa, A.M. (2009) Influence of nitrogen and boron nutrition on nutrient balance and sugar beet yield grown in calcareous soil. Ozean Journal of Applied Sciences, 2 (1), 1-10.

Jackson, M. I. (1973) "Soil Chemical Analysis”. Prentice Hall Inc. Englewood cliffs, N. J., U.S.A.

Javaheripour, M.A., Rashidi, N. and Baghizade, A. (2005) Manure, potassium and boron impacts on quantitative and qualitative yield of sugar beet in Bardsi. J. Sugar Beet, 21 (1), 23-56.

Kristek, A., Stojic, B. and Kristek, S. (2006) Effect of the foliar boron fertilization on sugar beet root yield and quality. Agric. Sci. Prof. Review,12 (1), 22-26.

Marrez, D. A., Naguib, M. M., Sultan, Y. Y., Daw, Z. Y. and Higazy, A. M. (2014). Evaluation of chemical composition for Spirulina platensis in different culture media. Res. J. Pharmaceutical, Biol. and Chem. Sci. 5 (4), 1161-1171.

Ma, T.S. and Zuazage, C. (1942) Micro-Kjeldahl determination of nitrogen a new indicator and an improved repaid method. Industry Eng. Chem. Anal. Ed. 14, 280.

Raupp, J. and Oltmanns, M. (2006) Farmyard manure, plant based organic fertilizers, inorganic fertilizer-which sustains soil organic matter best. Aspects of Applied Biology, 79, 273-276.

Shafeek, M.R., Helmy, Y.I., Omer, Nadia M. and Rizk, Fatma A. (2013) Effect of foliar fertilizer with nutritional compound and humic acid on growth and yield of broad bean plants under sandy soil conditions. J. Appl. Sci. Res. 9 (6), 3674-3680.

Snedecor, G.W. and Cochran, W.G. (1980) "Statistical Methods". $7^{\text {th }}$ ed. The Iowa State Univ. Press, Ames. Iowa, USA.

Wettstein, D. (1957) Chlorophyll, Letal_und der submikro svopische formmech, sallplastiden. Exptl Cell Ser. 12, 427-433 .

Wolf, B. (1974) Improvement in the azomethine-H method for the determination of boron. Comm. Soil Sci., Plant Anal. 5, 39-44. 
Yassen, A.A., Badran, N.M. and Zaghloul, S.M. (2007) Role of some organic residues as tools for reducing metals hazard in plant. World J. Agric. Sci. 3(2), 204-209.

Zhang, X. and Ervin, H. (2004) Seaweed extract and humic acid contain cytokinins. Crop. Sci. 44 (5), 1509.

\section{تأثير التغذية الورقية بمستخلص الطحالب والبورون على إنتاجية وجودة بنجر السكرالمنزرع فى الأراضي الرملية}

$$
\begin{aligned}
& \text { صلاح على عبد اللاة محمود عنان ، عبد الكريم محمد السعدى " وأبو الخير بدوى }
\end{aligned}
$$

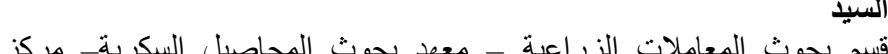

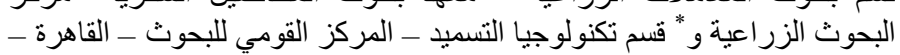

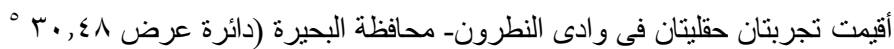

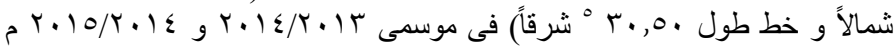

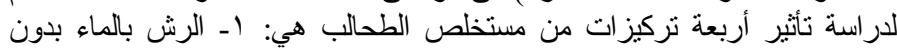

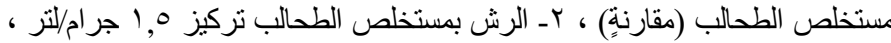

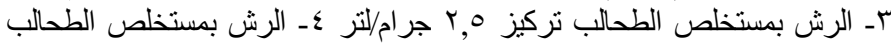

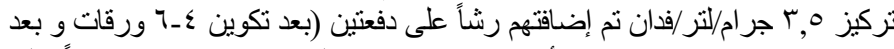

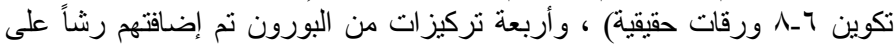
1. ورقات حقيقية) و هي: العين

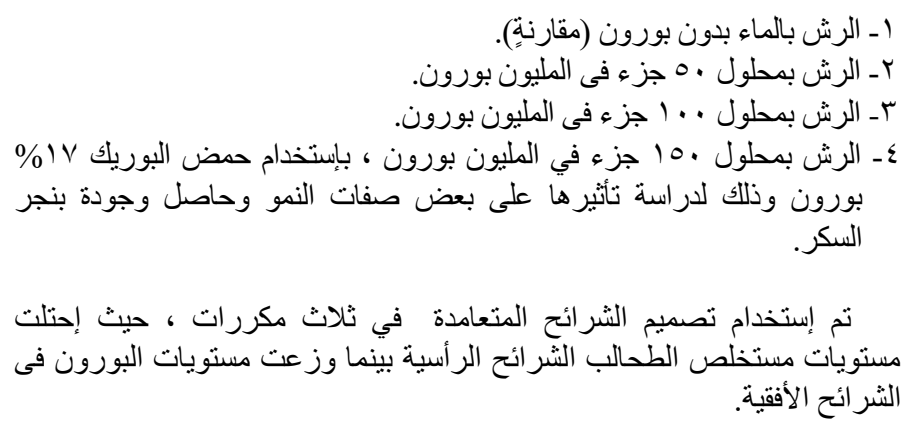




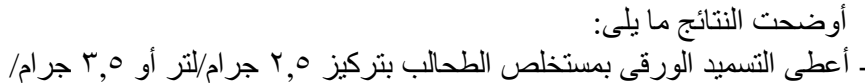

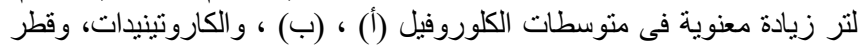

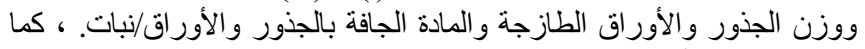

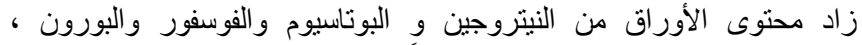

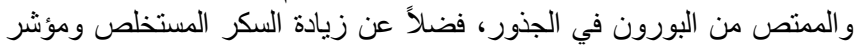
دليل الجودة مقارنة بالكنترول في كلا لجذور، الموسمين.

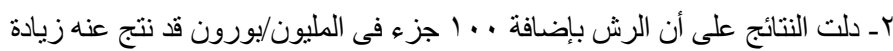

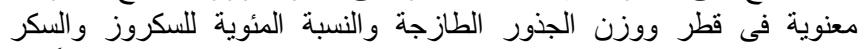

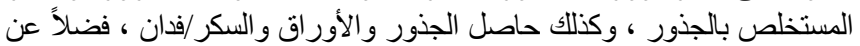
زيادة محتوى البورون في أوراق وجذور واصل بذور بنجر السكر.

rـ أظهر التفاعل بين التسميد بمستخلص الطحالب ومستويات البورون تأثثراً

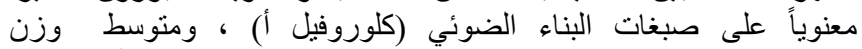

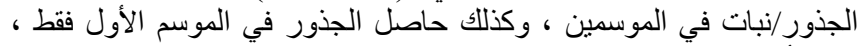

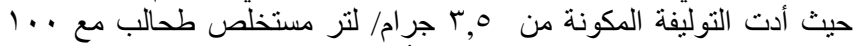

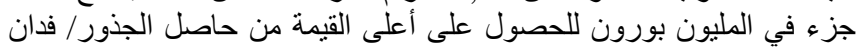
(T) هذه الصفات دوراً تكاملياً بين التسميد بمستخلص لتُ الطحالب و البورون.

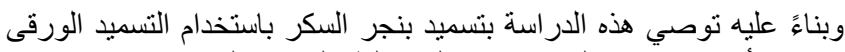

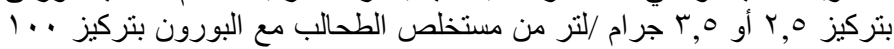
جزء فى المليون تحت ظروف أن التربة الرملية المروية بالرش. 